\title{
Isolation and partial characterization of the outer dense fibres and fibrous sheath from the sperm tail of a marsupial: the brushtail possum (Trichosurus vulpecula)
}

\author{
M. Ricci and W.G. Breed* \\ Department of Anatomical Sciences, The University of Adelaide, South Australia, 5005, Australia
}

The flagellum of a mammalian spermatozoon consists of a central axoneme surrounded by two cytoskeletal structures, the outer dense fibres and the fibrous sheath, which may aid in sperm motility or stability. In this study the outer dense fibres and fibrous sheath were isolated and partially characterized in a marsupial species, the brushtail possum (Trichosurus vulpecula). Spermatozoa from the cauda epididymidis were decapitated by sonication, and the head and tail fractions were separated by centrifugation over a 20,40 and $60 \%(w / v)$ sucrose density gradient. After confirming sperm tail purity by Nomarski microscopy, the tails were incubated in either SDS-dithiothreitol to isolate the outer dense fibres or urea-dithiothreitol to isolate the fibrous sheaths. Purified outer dense fibres and fibrous sheaths were solubilized in SDS and $\beta$-mercaptoethanol and proteins were separated by one-dimensional PAGE. Coomassie blue staining showed that the outer dense fibres were composed of seven major proteins (molecular masses: 73, 58, 55, 54, 52, 41 and $16 \mathrm{kDa}$ ), and the fibrous sheath was composed of 12 major proteins (molecular masses: 106, 76, 66, 62, 55, 53, 52, 46, 40, 30, 28 and $16 \mathrm{kDa}$ ). A polyclonal antibody to the fibrous sheath proteins showed strong crossreactivity with those of fibrous sheath from spermatozoa of several other marsupial species, as well as those from laboratory rats. Subsequent western blotting identified the immunoreactive 76 and $62 \mathrm{kDa}$ proteins from all species, thus indicating their high conservation between species. No crossreactivity of the fibrous sheath antibody to any other cytoskeletal structures, including the outer dense fibres, mid-piece fibre network or connecting laminae, or to the acrosome or underlying subacrosomal material, was evident, indicating that the fibrous sheath proteins are localized to this structure alone. Further work is in progress to determine the extent of homology of these proteins to those in eutherian mammals.

\section{Introduction}

The flagellum of a mammalian spermatozoon contains two cytoskeletal structures: the outer dense fibres and the fibrous sheath. The outer dense fibres connect to the connecting piece anteriorly and extend posteriorly into the principal piece for varying distances (Fawcett, 1975). There are nine outer dense fibres in the mid-piece and each is paired with a corresponding microtubule doublet of the axoneme (Fawcett, 1975). At the annulus, which marks the border between the mid- and principal piece, two of the nine outer dense fibres terminate, and the remaining fibres progressively decrease in size distally (Fawcett, 1970, 1975). The fibrous sheath is a tapering cylinder that surrounds the outer dense fibres in the principal piece and is composed of two structural elements: the longitudinal columns and the circumferential ribs. The longitudinal columns replace the two outer dense fibres that terminate at the annulus, whereas the circumferential ribs bridge the

*Correspondence

Email: william.breed@adelaide.edu.au longitudinal columns. The exact functions of the outer dense fibres and fibrous sheath are not clear, although the outer dense fibres may maintain a passive elastic recoil of the sperm tail (Olson and Sammons, 1980). In addition, the outer dense fibres may interact with the microtubule doublets to increase the bending torque generated by the axoneme (Lindemann, 1996). This increased torque, in conjunction with the additional stiffness provided by the outer dense fibres, may allow the axoneme to generate the forces necessary to produce and propagate bends in long sperm tails (Lindemann, 1996). The fibrous sheath may provide elastic rigidity to the sperm tail or define the shape of its beat by placing a constraint on its plane of bending (Philips, 1972; Fawcett, 1975; Lindemann et al., 1992; Si and Okuno, 1993; Carrera et al., 1994; Jassim, 1995).

The relative insolubility of the fibrous components of the sperm tail has allowed the outer dense fibres and fibrous sheath to be isolated for biochemical analysis. Different numbers of proteins in the outer dense fibres have been reported, with up to seven major proteins being described for the outer dense fibres of rats (Olson and Sammons, 1980; Vera et al., 1984; Oko, 1988; Kim et al., 1999), but only three proteins for the outer dense fibres of bulls 
(Baccetti et al., 1973, 1976; Brito et al., 1986) and humans (Haidl et al., 1991; Henkel et al., 1994). At least 17 major proteins have been identified in the fibrous sheath in rats (Olson et al., 1976; Oko, 1988; Kim et al., 1995a), with 14 and 10 proteins identified for humans (Jassim et al., 1992) and rabbits (Kim et al., 1995a), respectively.

Although the heads of marsupial spermatozoa differ radically from those of eutherian mammals, the structure of the flagellum appears, at least morphologically, to be somewhat similar. However, marsupial sperm tails possess additional cytoskeletal components. In some species these include connecting laminae, which extend from the outer dense fibres to the axoneme, and a mid-piece fibre network, which consists of a helically disposed parallel array of fibres immediately beneath the mid-piece plasma membrane (Cleland and Rothschild, 1958; Harding et al., 1979; TempleSmith, 1987, 1994). Other than a study demonstrating that there is a $32 \mathrm{kDa}$ protein in the fibrous sheath of spermatozoa from possums and wallabies (Harris and Rodger, 1998), the cytoskeletal components of the flagellum of marsupial spermatozoa have not been isolated or characterized. Therefore, the aim of the present study was to isolate and characterize the outer dense fibres and fibrous sheath proteins of a marsupial species, the brushtail possum (Trichosurus vulpecula). Polyclonal antibodies, raised against the possum fibrous sheath proteins, were used to determine the extent of antigen crossreactivity between proteins of fibrous sheath, outer dense fibres, mid-piece fibre network and connecting laminae, as well as between those of fibrous sheath, both within the marsupial lineage and between marsupials and eutherians.

\section{Materials and Methods}

\section{Experimental animals}

The following Australian marsupial species were used in this study: brushtail possum (Trichosurus vulpecula), tammar wallaby (Macropus eugenii), koala (Phascolarctos cinereus) and fat-tailed dunnart (Sminthopsis crassicaudata). All the animals, with the exception of the dunnarts, were captured from wild populations. The possums were trapped locally and housed at the Central Animal House of the University of Adelaide, whereas the wallabies were obtained on Kangaroo Island, South Australia. The koalas from which tissue was obtained came from the Adelaide Hills. The spermatozoa from dunnarts were obtained from individuals in a colony bred and housed at the Central Animal House. The University of Adelaide Ethics Committee approved all animal experimentation and the South Australian National Parks and Wildlife Service approved the use of protected animals.

The animals were killed by $\mathrm{CO}_{2}$ asphyxiation. The cauda epididymides were dissected free, minced in $5 \mathrm{ml} 0.02 \mathrm{~mol}$ PBS $\mathrm{I}^{-1}$, $\mathrm{pH} 7.4$, and the spermatozoa released were centrifuged at $700 \mathrm{~g}$ for $10 \mathrm{~min}$. The spermatozoa were washed twice with PBS and resuspended in $5 \mathrm{ml}$ buffer.
From this point onwards, all steps were carried out at $4{ }^{\circ} \mathrm{C}$ unless indicated otherwise and $0.2 \mathrm{mmol}$ phenylmethylsulphonyl fluoride (PMSF) $\mathrm{I}^{-1}$ (Oko, 1988) was added to the buffers.

\section{Isolation of possum sperm tails}

The spermatozoa in suspension were decapitated by sonication (Sanophon sonicator, Sydney) for 4-6 $15 \mathrm{~s}$ bursts at $30 \mathrm{~s}$ intervals. The decapitated spermatozoa were washed in PBS-PMSF, resuspended in 20\% (w/v) sucrose in PBS-PMSF, layered over a 20, 40 and 60\% sucrose gradient, and centrifuged at $3000 \mathrm{~g}$ for $90 \mathrm{~min}$ in a refrigerated swinging bucket rotor (Beckman, model TJ-6). Sperm tail fractions were collected from the $40-60 \%$ sucrose interface and purity was assessed by Nomarski microscopy. In most instances there was no more than about 5\% contamination with sperm heads. The sperm tail fraction was resuspended in $20 \%$ (w/v) sucrose and centrifuged again at $3000 \mathrm{~g}$ through a 20, 40 and $60 \%$ sucrose step gradient for $60 \mathrm{~min}$; in these samples, sperm tails collected from the $40-60 \%$ interface contained $<1 \%$ sperm head contamination. The sperm were subsequently diluted with PBS-PMSF and pelleted by centrifugation at $15000 \mathrm{~g}$ for $10 \mathrm{~min}$.

\section{Isolation of the outer dense fibres}

The isolated sperm tails were suspended in $5 \mathrm{ml} 1 \%$ (w/v) SDS, $2 \mathrm{mmol}$ dithiothreitol $\mathrm{I}^{-1}$ (DTT), in $25 \mathrm{mmol}$

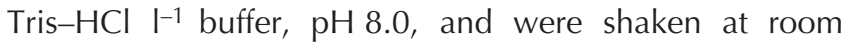
temperature for 30, 60, 90 or $120 \mathrm{~min}$. The resultant suspensions were diluted with Tris- $\mathrm{HCl}$, layered over a 20, 40 and $60 \%$ sucrose gradient and centrifuged at $3000 \mathrm{~g}$ for $60 \mathrm{~min}$. The outer dense fibres were collected from the 40-60\% sucrose interface, washed in Tris-HCl buffer, and pelleted by centrifugation at $15000 \mathrm{~g}$ for $30 \mathrm{~min}$. The pellet was either fixed for routine transmission electron microscopy or frozen at $-70^{\circ} \mathrm{C}$ for later use.

\section{Isolation of the fibrous sheath}

The isolated sperm tails were suspended in $2 \%(\mathrm{v} / \mathrm{v})$ Triton X-100, 5 mmol DTT I-1, in 50 mmol Tris-HCl buffer $\mathrm{I}^{-1}$, $\mathrm{pH}$ 9.0, with shaking at $4^{\circ} \mathrm{C}$ for $15 \mathrm{~min}$. The resultant suspension was centrifuged at $1000 \mathrm{~g}$ for $10 \mathrm{~min}$; the supernatant was discarded and the procedure was repeated. This procedure was carried out to solubilize all membranous sperm tail components. The pellet was resuspended in $5 \mathrm{ml} 4.5 \mathrm{~mol}$ urea $\mathrm{I}^{-1}, 25 \mathrm{mmol}$ DTT $\mathrm{I}^{-1}$, in $25 \mathrm{mmol}$ Tris- $\mathrm{HCl}$ buffer $\mathrm{I}^{-1}, \mathrm{pH} 8.0$, at $4^{\circ} \mathrm{C}$ for either 3,5 or $8 \mathrm{~h}$ with gentle shaking. The resultant suspension was diluted with Tris- $\mathrm{HCl}$ buffer and layered over a 20, 40 and 60\% sucrose gradient and centrifuged at $3000 \mathrm{~g}$ for $60 \mathrm{~min}$. The fibrous sheaths were collected from the $40-60 \%$ sucrose interface, washed in Tris-HCl buffer and pelleted by centrifugation at $15000 \mathbf{g}$ for $30 \mathrm{~min}$. The pellet was either fixed for routine transmission electron microscopy or frozen at $-70^{\circ} \mathrm{C}$ for later use. 


\section{SDS-PAGE}

Isolated outer dense fibres and fibrous sheaths were solubilized in $2 \%(\mathrm{w} / \mathrm{v})$ SDS and $5 \%(\mathrm{v} / \mathrm{v}) \beta$-mercaptoethanol for $5 \mathrm{~min}$ at $100^{\circ} \mathrm{C}$, and any insoluble material was removed by centrifugation at $15000 \mathrm{~g}$ for $20 \mathrm{~min}$. Protein concentrations were determined using the Bio-Rad protein assay (Bio-Rad Laboratories, Hercules, CA), and the proteins were separated on linear gradient $(7.5 \%-15 \%)$ SDSpolyacrylamide gels. Up to $50 \mu \mathrm{g}$ protein per lane was used and the gels were stained with Coomassie brilliant blue. Broad range molecular weight standards (Bio-Rad) were used to determine the molecular weights of the proteins.

\section{Polyclonal antibody preparation}

The outer dense fibres and fibrous sheath fractions were solubilized as described above, and each denatured component was emulsified in an equal volume of Freund's complete adjuvant (Sigma, St Louis, MO). Approximately $50 \mu \mathrm{g}$ protein was injected either i.p. or s.c. into SpragueDawley rats. The rats were given a booster injection with $50 \mu \mathrm{g}$ solubilized protein in an equal volume of Freund's incomplete adjuvant at 2 week intervals for 6 weeks and test blood collections were carried out 7 days after each booster injection. Serum was collected and stored at $-70^{\circ} \mathrm{C}$. Pre-immune sera were collected from all rats before immunization.

\section{Western blotting}

Spermatozoa from the cauda epididymidis of laboratory rats, wallabies, dunnarts and koalas were solubilized in $4.5 \mathrm{~mol}^{-1} \mathrm{Irea}^{-1}$ and $2 \%(\mathrm{w} / \mathrm{v})$ SDS in $25 \mathrm{mmol}^{\mathrm{DTT}} \mathrm{I}^{-1}$ for $5 \mathrm{~h}$ at room temperature. Insoluble material was removed by centrifugation at $15000 \mathrm{~g}$ for $20 \mathrm{~min}$ and final protein concentration was determined. Proteins were separated on $7-12 \%(w / v)$ SDS-polyacrylamide mini gels (Bio-Rad) and up to $10 \mu \mathrm{g}$ protein was loaded per lane. Electrophoretic transfer of the proteins from the gels to the nitrocellulose membrane was carried out in a Trans-blot cell (Bio-Rad) in $25 \mathrm{mmol} \mathrm{Na}_{2} \mathrm{HPO}_{4}$ buffer $\mathrm{l}^{-1}$ at pH 6.4, $300 \mathrm{~V}$, for $1 \mathrm{~h}$. After removal from the transfer apparatus, the gels were stained with Coomassie brilliant blue and the nitrocellulose membrane was stained temporarily with $0.2 \%(\mathrm{w} / \mathrm{v})$ Ponceau in $10 \%(\mathrm{v} / \mathrm{v})$ acetic acid to determine the effectiveness of the transfers. The blots were destained and blocked by incubating overnight at $4{ }^{\circ} \mathrm{C}$ with $5 \%(\mathrm{w} / \mathrm{v})$ nonfat milk powder in TBS-Tween $(25 \mathrm{mmol}$ Tris- $\mathrm{HCl}$ buffered saline $\mathrm{I}^{-1}, \mathrm{pH} 7.4$, containing $0.1 \%(\mathrm{v} / \mathrm{v})$ Tween-20). The blots were washed in TBS-Tween and incubated with immune serum, diluted 1:100 in TBS-Tween, for $1 \mathrm{~h}$ at room temperature. The blots were subsequently rinsed four times in TBS-Tween at 5 min per time, and incubated with biotinylated goat anti-rat immunoglobulin antiserum (Zymed, San Francisco, CA), diluted 1:1000 in TBS-Tween for $1 \mathrm{~h}$ at room temperature. The blots were washed in TBS-Tween as described and incubated with strepavidin-
AP (Amersham, Castle Hill, Sydney) diluted 1:3000 in TBSTween for a further $1 \mathrm{~h}$. The blots were developed with $10 \mathrm{ml}$ of 5'-bromo-4-chloro-3-indolyl phosphate/nitro blue tetrazolium (BCIP/NBT) liquid substrate system (Sigma). Controls consisted of replacing the primary antibody with pre-immune serum or buffer.

\section{Indirect immunofluorescence microscopy}

Possum, koala, wallaby, dunnart and rat spermatozoa from cauda epididymidis were washed in PBS, $\mathrm{pH} 7.4$, and fixed in $3 \%(\mathrm{v} / \mathrm{v})$ paraformaldehyde in $\mathrm{PBS}$ at $4^{\circ} \mathrm{C}$ for $20 \mathrm{~min}$. Reactive aldehyde groups were blocked by resuspending the fixed spermatozoa in PBS containing $50 \mathrm{mmol}$ glycine $\mathrm{I}^{-1}$ for $20 \mathrm{~min}$, and $100 \mu \mathrm{l}$ aliquots were spotted on glass slides pre-coated with 3-aminopropyltriethoxysilane (APES), for $2 \mathrm{~h}$ at $4^{\circ} \mathrm{C}$. The slides were rinsed four times with PBS, $\mathrm{pH} 7.4$, and the spermatozoa were permeabilized with ice-cold acetone for $5 \mathrm{~min}$. The spermatozoa were rinsed four times in PBS and incubated with $10 \%$ normal goat serum (NGS) in PBS for 20 min to reduce non-specific binding. The spermatozoa were then incubated overnight at $4^{\circ} \mathrm{C}$ with antiserum diluted 1:100 in PBS containing $0.1 \%$ BSA and $1 \%$ NGS. The slides were rinsed four times in PBS, incubated in PBS containing 10\% NGS for $15 \mathrm{~min}$ and then incubated with FITC-conjugated goat anti-rat IgG (Sigma) diluted 1:50 in PBS containing $0.1 \%$ BSA and $1 \%$ NGS for 45 min. Non-specific staining was determined by replacing the primary antiserum with pre-immune serum or PBS and autofluorescence was determined by omitting the second antibody.

\section{Immunogold electron microscopy}

Adult male possums were anaesthetized with isofluorane, and testes and epididymides were fixed by perfusion for $20 \mathrm{~min}$ with $4 \%(\mathrm{v} / \mathrm{v})$ paraformaldehyde in $0.2 \mathrm{~mol}^{\mathrm{PBS}} \mathrm{I}^{-1}, \mathrm{pH}$ 7.4. Tissue was dissected free and immersed in the same fixative for $2 \mathrm{~h}$, washed in two changes of PBS and dehydrated by passing through a graded series of ethanol. The tissue was infiltrated in a 2:1 ratio of LR White:70\% (v/v) ethanol for $1 \mathrm{~h}$, followed by two further incubations in pure LR White resin for $1 \mathrm{~h}$ and then overnight. The resin was again replaced just before polymerization in gelatin capsules at $60^{\circ} \mathrm{C}$ for $24 \mathrm{~h}$. Ultrathin sections were cut on a Reichert Jung Ultracut microtome and mounted on nickel grids.

Sections on grids were blocked by incubation in $10 \%$ NGS for $30 \mathrm{~min}$ and incubated with the polyclonal antibody diluted 1:100 in TBS-Tween containing 1\% NGS. The grids were washed six times for $5 \mathrm{~min}$ each in TBS-Tween and further blocked in 10\% NGS for $15 \mathrm{~min}$ before incubation in $10 \mathrm{~nm}$ gold-conjugated goat anti-rat immunoglobulin (Sigma) diluted 1:20, for $1 \mathrm{~h}$ at room temperature. The grids were washed six times for $5 \mathrm{~min}$ each in TBS-Tween and four times for 5 min each in $\mathrm{dd}_{2} \mathrm{O}$. The grids were finally stained with uranyl acetate 
(3 min) and examined on a Phillips CM100 transmission electron microscope at $80 \mathrm{kV}$.

\section{Transmission electron microscopy}

Possum cauda epididymides, and isolated outer dense fibres and fibrous sheaths, were fixed by immersion in 3\% $(\mathrm{v} / \mathrm{v})$ paraformaldehyde and $3 \%(\mathrm{v} / \mathrm{v})$ glutaraldehyde in 0.2 mol phosphate buffer $\mathrm{I}^{-1}$ for $4 \mathrm{~h}$, washed in two changes of buffer and post-fixed in $1 \%(\mathrm{v} / \mathrm{v})$ osmium tetroxide in PBS for $1 \mathrm{~h}$. After washing in buffer, the tissue was dehydrated by passing through a graded series of ethanol, cleared in propylene oxide, and infiltrated in a 1:1 ratio of propylene oxide:resin overnight. Propylene oxide:resin was replaced with pure resin for $24 \mathrm{~h}$ before the tissue was polymerized at $60^{\circ} \mathrm{C}$ for $48 \mathrm{~h}$. Ultrathin sections were cut, mounted on copper grids, stained with uranyl acetate and lead citrate, and examined on a Phillips CM100 transmission electron microscope at $80 \mathrm{kV}$.

\section{Ruthenium red staining of spermatozoa}

Possum spermatozoa from the cauda epididymidis were fixed in $3 \%(\mathrm{v} / \mathrm{v})$ glutaraldehyde containing $0.5 \%(\mathrm{w} / \mathrm{v})$ ruthenium red in 0.2 mol cacodylate buffer ${ }^{-1}, \mathrm{pH}^{7.4}$, for $4 \mathrm{~h}$, washed in two changes of buffer containing $0.5 \%(\mathrm{w} / \mathrm{v})$ ruthenium red, and post-fixed in $1 \%(\mathrm{v} / \mathrm{v})$ osmium tetroxide in buffer containing $0.5 \%(\mathrm{w} / \mathrm{v})$ ruthenium red. After washing in buffer, the spermatozoa were processed and stained for routine transmission electron microscopy.

\section{Results}

\section{Morphology of possum sperm tails}

The flagellum of possum spermatozoa consists of: (i) a mid-piece, in which a mitochondrial sheath surrounds nine outer dense fibres, together with a fibre network that is composed of parallel rows of fibres beneath the plasma membrane (Fig. 1a,b,c); and (ii) a principal piece, consisting of outer dense fibres, which progressively decreases in size distally, surrounded by a fibrous sheath (Fig. 1a,b). Ruthenium red fixation of possum spermatozoa from the cauda epididymidis showed that the fibrous sheath appeared homogeneous (not shown), whereas the outer dense fibres contained two distinct regions: a narrow, electron dense, outer C-shaped cortex and a central medulla (Fig. 1c,d).

\section{Isolation of possum sperm tails}

Sonication of possum spermatozoa from the cauda epididymidis for six $15 \mathrm{~s}$ bursts at $100 \%$ output resulted in the decapitation of about $95 \%$ of the spermatozoa. Subsequent sucrose gradient centrifugation (Fig. 2a) resulted in the deposition of relatively pure fractions of red blood cells and what appeared to be cytoplasmic droplets at the $20-40 \%$ sucrose interface (Fig. 2 b), sperm tails at the
$40-60 \%$ sucrose interface (Fig. 2c) and sperm heads at the bottom of the $60 \%$ sucrose layer (Fig. $2 \mathrm{~d}$ ).

The red blood cells originated from epididymal blood vessels that were severed at the time of obtaining spermatozoa from the cauda epididymidis when the duct was cut into several pieces, whereas the cytoplasmic droplets were shed from spermatozoa during epididymal transit.

Sonication and subsequent centrifugation removed most of the plasma membrane and mid-piece fibre network from the spermatozoa, but the mitochondrial sheath, outer dense fibres and fibrous sheath remained intact (Fig. 2c). The plasma membrane and most of the acrosomal material were similarly removed from the isolated sperm heads, although in some sperm heads acrosomes with marked vacuolation of acrosomal material or remnants of acrosomal matrix were observed (Fig. 2d).

\section{Isolation of possum outer dense fibres}

Incubation of the isolated sperm tails in $1 \%(\mathrm{w} / \mathrm{v})$ SDS

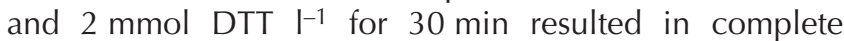
solubilization of the axoneme and fibrous sheath, although remnants of the mitochondria remained (Fig. 3a). After $60 \mathrm{~min}$ of incubation the outer dense fibres and the connecting piece were still present (not shown) but by 90 min of incubation only the outer dense fibres remained (Fig. 3b), with some thin fibres occurring that were presumed to contain outer dense fibre material (Fig. 3c). Incubation of this material in SDS-DTT for an additional $30 \mathrm{~min}$ resulted in complete solubilization of the thin fibres and swelling of the remaining outer dense fibres, although they retained their overall shape (Fig. 3d).

\section{Isolation of possum fibrous sheath}

Incubation of the sperm tails in $2 \%(\mathrm{v} / \mathrm{v})$ Triton X-100 and $5 \mathrm{mmol}^{\mathrm{DTT}} \mathrm{I}^{-1}$ for two 15 min periods resulted in complete solubilization of the remaining mid-piece fibre networks, as well as the mitochondrial sheath, which exposed the outer dense fibres of the mid-piece (Fig. 4a). Subsequent treatment of sperm tails with $4.5 \mathrm{~mol}^{-} \mathrm{urea}^{-1}$ and $25 \mathrm{mmol}$ DTT $\mathrm{I}^{-1}$ for $3 \mathrm{~h}$ resulted in complete solubilization of the axoneme and disruption and partial solubilization of the outer dense fibres (Fig. 4b). After $5 \mathrm{~h}$ the fibrous sheath remained with occasional remnants of outer dense fibres persisting (Fig. 4c). Prolonged exposure of sperm tails to urea-DTT (up to $8 \mathrm{~h}$ ) to remove remnants of outer dense fibres resulted in the disruption of the fibrous sheath with some of the outer dense fibre remnants still remaining (Fig. 4d).

\section{Polypeptide composition of possum outer dense fibres and fibrous sheath}

One-dimensional SDS polyacrylamide gels of isolated outer dense fibres after $90 \mathrm{~min}$ of incubation revealed the presence of seven major Coomassie brilliant blue-stained protein bands (Fig. 5, lane 1) (molecular masses: 73, 58, 55, 

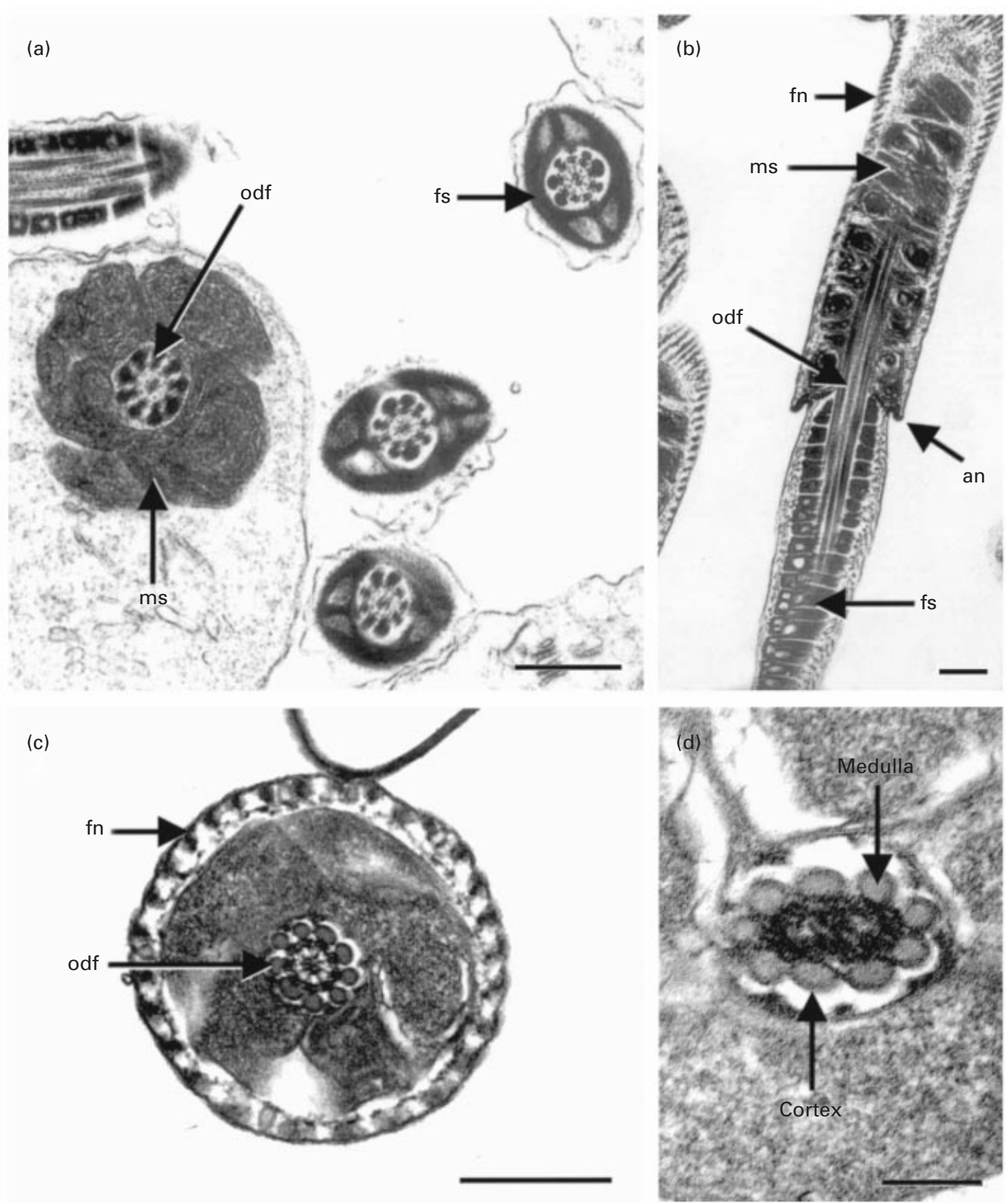

Fig. 1. Transmission electron micrographs of (a) transverse and (b) longitudinal sections of possum spermatozoa from cauda epididymidis. The outer dense fibres (odf) in the mid-piece are surrounded by a mitochondrial sheath (ms) and mid-piece fibre network (fn), whereas the outer dense fibres in the principal piece are surrounded by the fibrous sheath ( $\mathrm{fs}$ ). The annulus (an) marks the border between the mid- and principal piece. (c,d) Transmission electron micrographs of transverse sections through the mid-piece of possum spermatozoa from cauda epididymidis fixed in the presence of ruthenium red. The outer dense fibres are composed of a narrow electron-dense peripheral, C-shaped cortex and a central medulla that is less electron-dense. Scale bars represent $(\mathrm{a}, \mathrm{b}, \mathrm{c}) 0.5$ and $(\mathrm{d}) 1.5 \mu \mathrm{m}$.

54, 52, 41 and $16 \mathrm{kDa}$ ). Subsequent silver staining of these outer dense fibre gels revealed an additional 11 minor bands (Fig. 5, lane 2) (molecular masses: 106, 64, 43, 34, 32, 30, 29, 28, 26, 25 and $21 \mathrm{kDa})$. The 39-42 kDa and 15-17 kDa protein smears observed after silver staining presumably originated from the 41 and $16 \mathrm{kDa}$ outer dense fibre protein bands, respectively, as identified by Coomassie staining. The most prominent outer dense fibre protein bands had molecular masses of 73, 55, 41 and $16 \mathrm{kDa}$. SDS-polyacrylamide gels were also run of fractions of outer 
Table 1. Molecular masses of fibrous sheath proteins of several species identified by western blotting with anti-possum fibrous sheath serum

\begin{tabular}{|c|c|c|c|c|c|}
\hline $\begin{array}{l}\text { Possum } \\
\text { fibrous sheath }\end{array}$ & $\begin{array}{l}\text { Possum outer } \\
\text { dense fibres }\end{array}$ & $\begin{array}{c}\text { Rat } \\
\text { spermatozoa }\end{array}$ & $\begin{array}{c}\text { Wallaby } \\
\text { spermatozoa }\end{array}$ & $\begin{array}{c}\text { Dunnart } \\
\text { spermatozoa }\end{array}$ & $\begin{array}{c}\text { Koala } \\
\text { spermatozoa }\end{array}$ \\
\hline 106 & - & 106 & - & 106 & 106 \\
\hline 76 & - & 76 & 76 & 76 & 76 \\
\hline 62 & - & 62 & 62 & 62 & 62 \\
\hline- & - & - & 48 & - & 48 \\
\hline- & - & 45 & - & 45 & - \\
\hline 40 & - & - & - & - & - \\
\hline- & - & - & 39 & - & - \\
\hline- & - & - & 37 & - & - \\
\hline- & - & - & - & 35 & - \\
\hline- & - & - & 34 & - & - \\
\hline- & - & - & 32 & - & - \\
\hline- & - & 27 & 27 & - & - \\
\hline- & - & 20 & 20 & - & 20 \\
\hline 16 & - & - & 16 & - & 16 \\
\hline- & - & 14 & - & 14 & - \\
\hline
\end{tabular}

All molecular masses are in kDa.

dense fibres incubated in SDS-DTT for $120 \mathrm{~min}$, at which stage the cortex-like fragments of the outer dense fibres had solubilized and only the medulla appeared to remain. Silver staining of these gels revealed that only two of seven major possum outer dense fibre protein bands, the 41 and $16 \mathrm{kDa}$ proteins, remained (Fig. 6).

One-dimensional SDS-polyacrylamide gels of isolated fibrous sheath after $5 \mathrm{~h}$ of incubation revealed the presence of 12 major protein bands stained by Coomassie blue (molecular masses: 106, 76, 66, 62, 55, 53, 52, 46, 40, 30, 28 and $16 \mathrm{kDa}$ ) (Fig. 5, lane 3). Subsequent silver staining revealed three additional minor bands (molecular masses: 35, 29 and $22 \mathrm{kDa}$ ) (Fig. 5, lane 4). The most prominent fibrous sheath protein bands have molecular masses of 76 , 66, 62, 52 and $40 \mathrm{kDa}$.

All gels were repeated at least twice with samples from five different incubations of outer dense fibre and fibrous sheath, and the protein bands described consistently appeared in all gels.

\section{Immunocytochemistry}

Only a weak antibody response was observed in laboratory rats immunized with solubilized outer dense fibres and, thus, further work with these antibodies was not performed. In contrast, a very strong antibody response was observed in each of the rats immunized with solubilized fibrous sheath proteins.

The possum fibrous sheath antiserum reacted strongly and specifically with proteins of the principal piece of permeabilized possum spermatozoa from cauda epididymidis (Fig. 7a,b), with no staining observed for any of the proteins of the mid-piece or sperm head. This observation indicates that the possum fibrous sheath proteins to which the antibody bound are different from those of the outer dense fibres and mid-piece fibre network, and from those of the acrosome and underlying subacrosomal material. Intense fluorescence was also observed over the principal piece in permeabilized koala (Fig. 8a,b), dunnart (Fig. 8c,d) and wallaby (Fig. 8e,f) spermatozoa, with less intense and patchy, but still strong, fluorescence over the principal piece of laboratory rat spermatozoa (Fig. 8g,h). No staining of the sperm head or mid-piece components was evident in any of these species.

Ultrastructural localization of the fibrous sheath antiserum to possum spermatozoa from the cauda epididymidis showed distinct immunogold labelling over the entire fibrous sheath (Fig. 7c,d), but no antibody reactivity was observed over the outer dense fibres, mitochondrial sheath, mid-piece fibre network, acrosome or subacrosomal material. The same pattern of immunogold labelling was also observed over spermatozoa from the dunnart cauda epididymidis (not shown). These dunnart spermatozoa also have connecting laminae that occur between the outer dense fibres and axoneme, and the antibody did not bind to material in these structures.

\section{Western blotting}

Immune serum raised against the fibrous sheath proteins reacted strongly with the major fibrous sheath polypeptides of molecular masses 106, 76, 62, 40 and 16 kDa (Fig. 9, lane 1). No crossreactivity was observed with the possum outer dense fibre proteins (Fig. 9, lane 2). In addition, the antibody crossreacted with proteins from whole laboratory rat, wallaby, dunnart and koala sperm extracts (Fig. 9, lanes 3-6; Table 1). The antibody crossreacted with the 76 and $62 \mathrm{kDa}$ proteins from all four species, as well as the $106 \mathrm{kDa}$ protein from rats, dunnarts and koalas, the $45 \mathrm{kDa}$ proteins from rats and dunnarts, and the $48 \mathrm{kDa}$ proteins from wallabies and koalas 
(a)

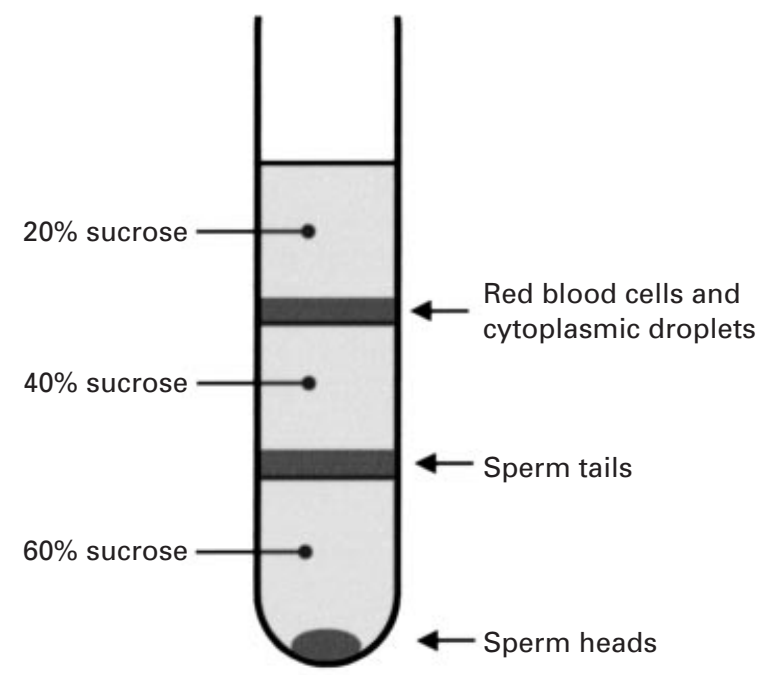

(c)
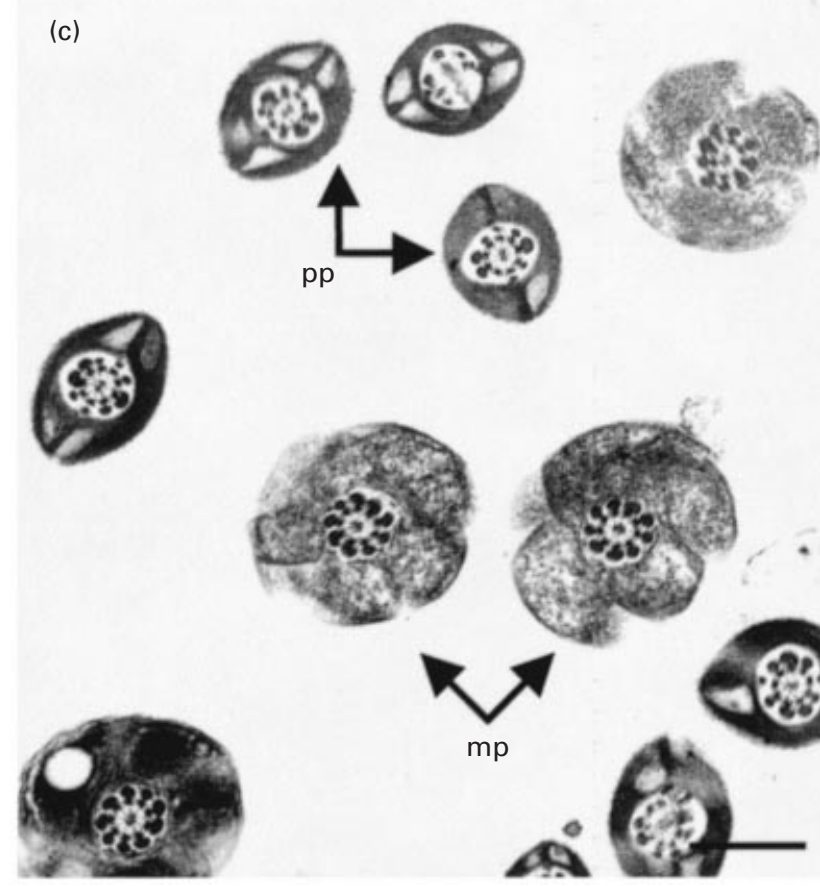

Fig. 2. (a) Sonication and sucrose density gradient centrifugation of possum spermatozoa from cauda epididymidis resulted in the deposition of (b) red blood cells (rbc) and cytoplasmic droplets (cd) at the $20-40 \%$ (w/v) sucrose interface, (c) sperm tails at the $40-60 \%$ interface and (d) sperm heads at the bottom of the $60 \%$ sucrose layer. Acrosomes on the isolated sperm heads are vacuolated or their matrix is dispersed (arrows). pp: principal piece; mp: mid-piece. Scale bars represent (b,c) 0.5 and (d) $1.0 \mu \mathrm{m}$.

(Fig. 9, lanes 3-6). Additional proteins were immunostained in each species, especially in extracts of wallaby spermatozoa (see Table 1). No staining was observed when immune serum was replaced with pre-immune serum (Fig. 9, lanes 7-12).
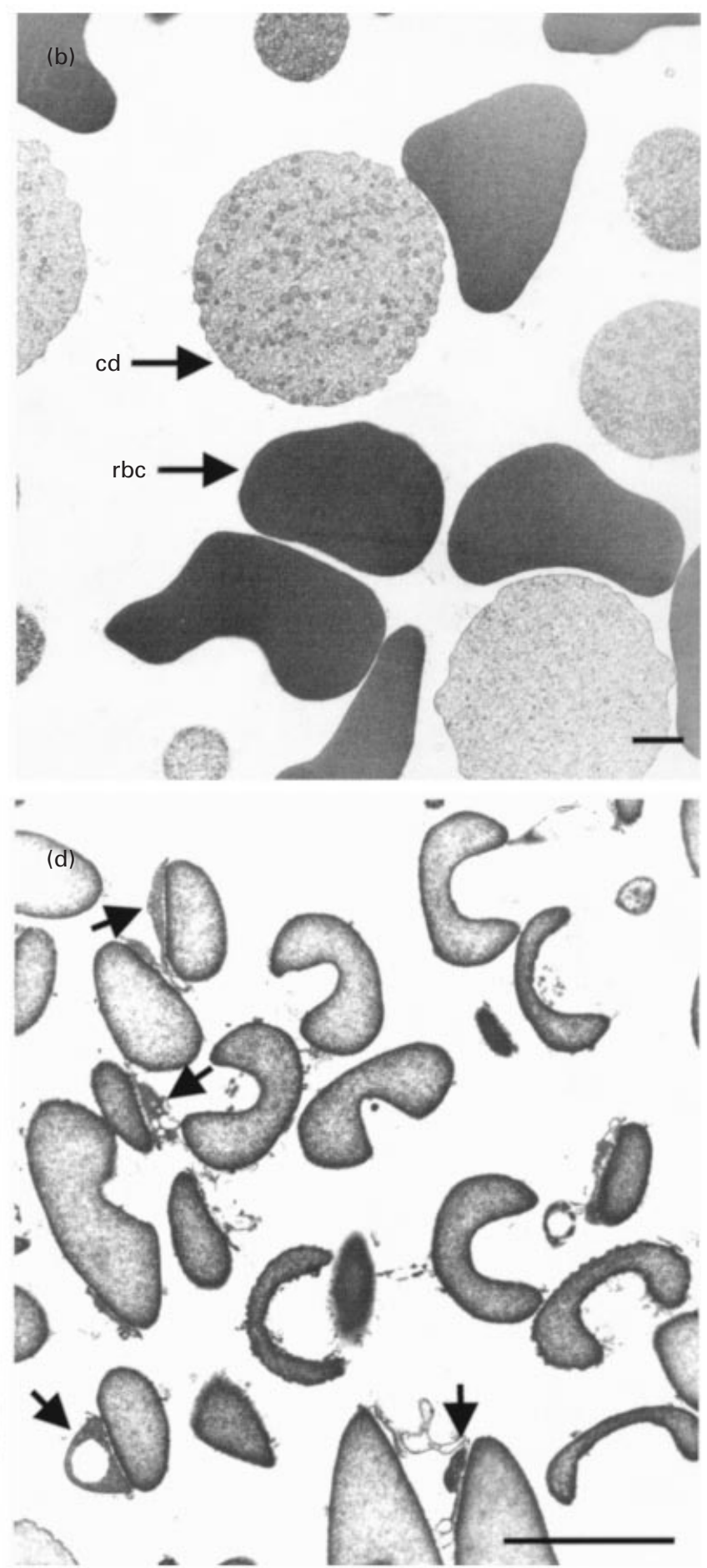
(a)

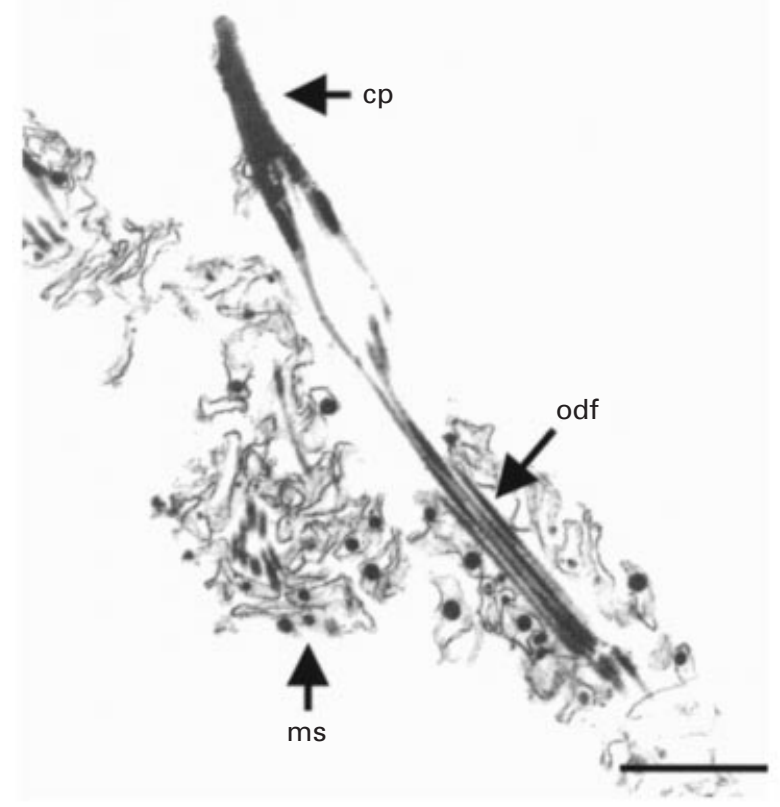

(b)
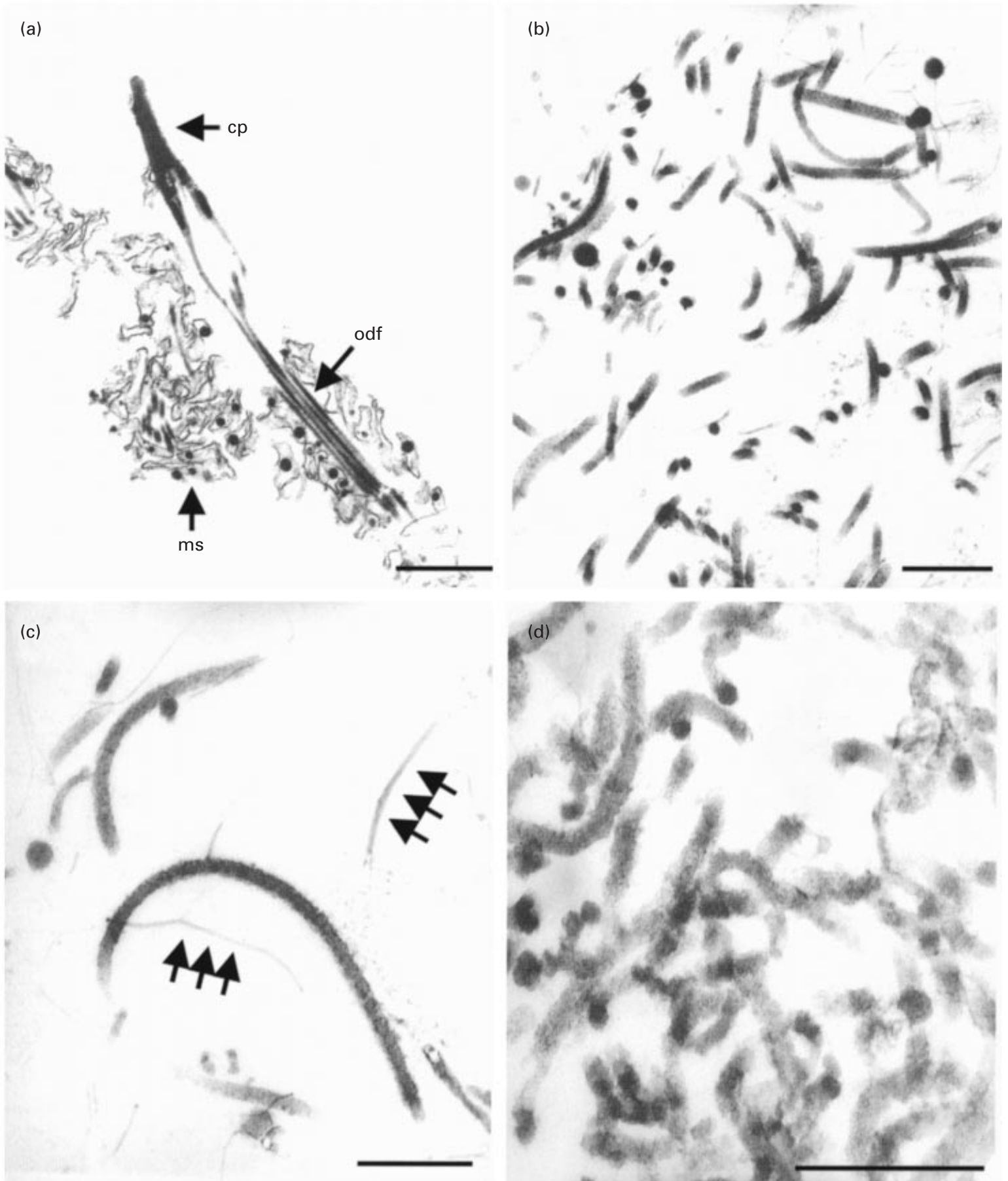

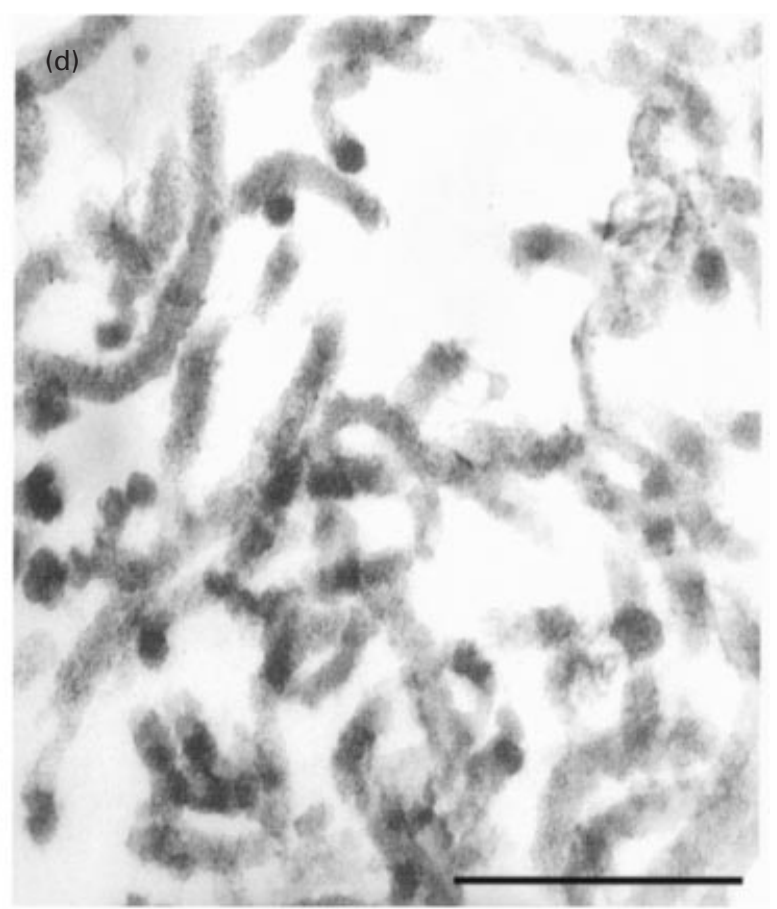

Fig. 3. Incubation of possum sperm tails in SDS-dithiothreitol for (a) 30 min resulted in solubilization of all sperm tail components with the exception of the outer dense fibres (odf), connecting piece (cp) and fragments of the mitochondrial sheath (ms). (b) After 90 min of incubation, only the outer dense fibres remained and (c) thin fibres of the outer dense fibres (arrows) were detached from the main portion. (d) Incubation for 120 min resulted in solubilization of the thin fibres and swelling of the larger outer dense fibres. Scale bars represent (a) 0.50 , (b) 0.10 and (c,d) $0.05 \mu \mathrm{m}$.

possum, were isolated and the protein composition determined by one-dimensional PAGE. The techniques used to isolate these cytoskeletal structures were adapted from those used for similar studies on laboratory rats (see Oko, 1988). In addition, a polyclonal antibody raised against the possum fibrous sheath proteins showed strong crossreactivity by immunofluorescence, immunogold electron microscopy and western blotting with proteins of the fibrous sheath of spermatozoa from dunnarts, koalas, wallabies and laboratory rats. This finding indicates that 

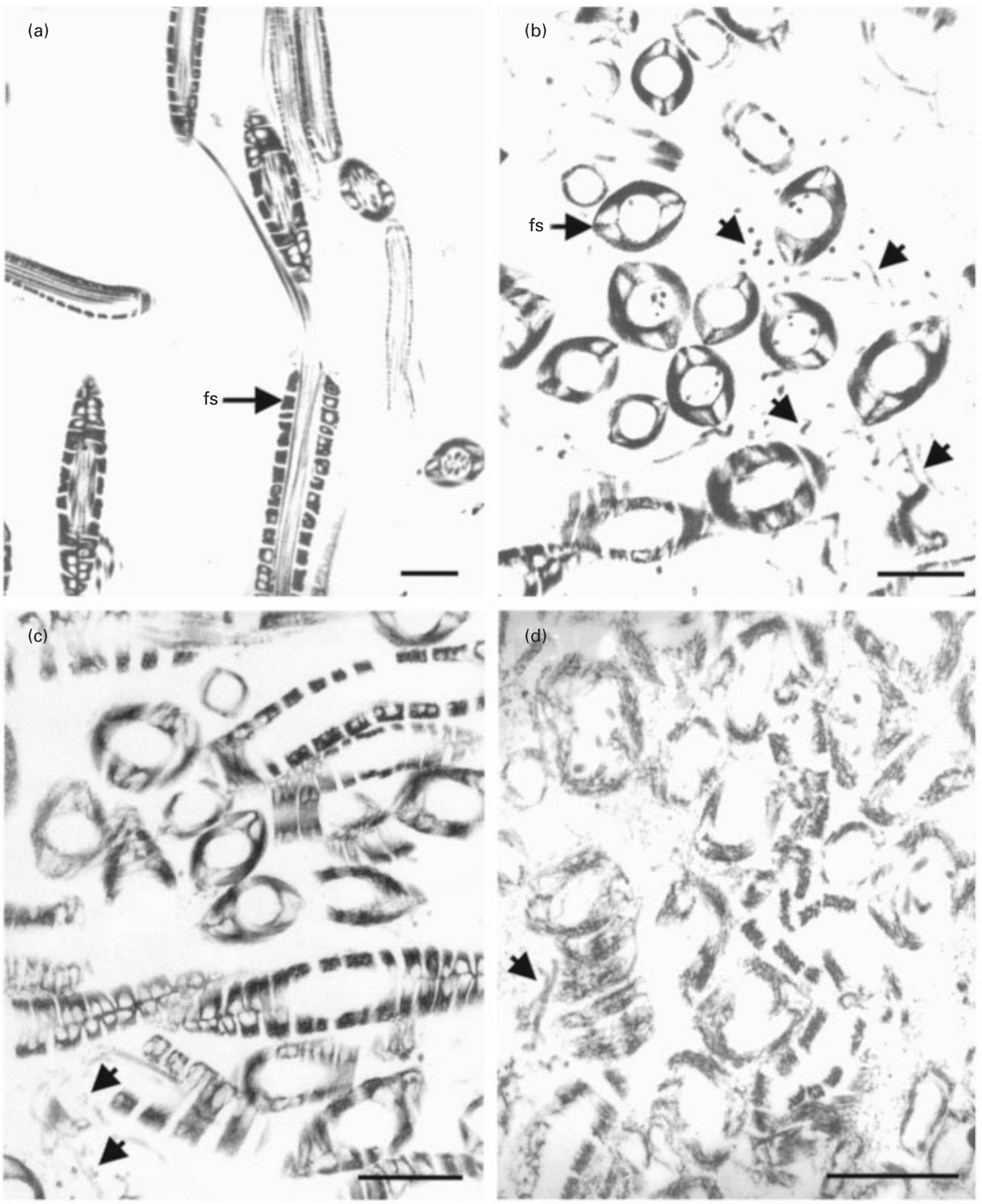

Fig. 4. (a) Incubation of possum sperm tails in Triton X-100-dithiothreitol resulted in solubilization of the mitochondrial sheath. Subsequent incubation in urea-dithiothreitol for (b) $3 \mathrm{~h}$ resulted in solubilization of axoneme and disruption of the outer dense fibres (arrows), whereas (c) incubation for $5 \mathrm{~h}$ resulted in solubilization of most of the outer dense fibres (arrows). (d) After $8 \mathrm{~h}$ of incubation, the fibrous sheath ( $\mathrm{fs}$ ) began to degenerate but small fragments of outer dense fibres still persisted (arrow). Scale bars represent $0.5 \mu \mathrm{m}$.

there is high conservation of at least some of these proteins across marsupial, and even a eutherian, species. However, there was no crossreactivity of this antibody to any outer dense fibre, mid-piece fibre network or connecting laminae proteins from the sperm tail, or to the acrosome or underlying subacrosomal material, indicating that these structures have very different proteins from those that make up the fibrous sheath. 
(a)

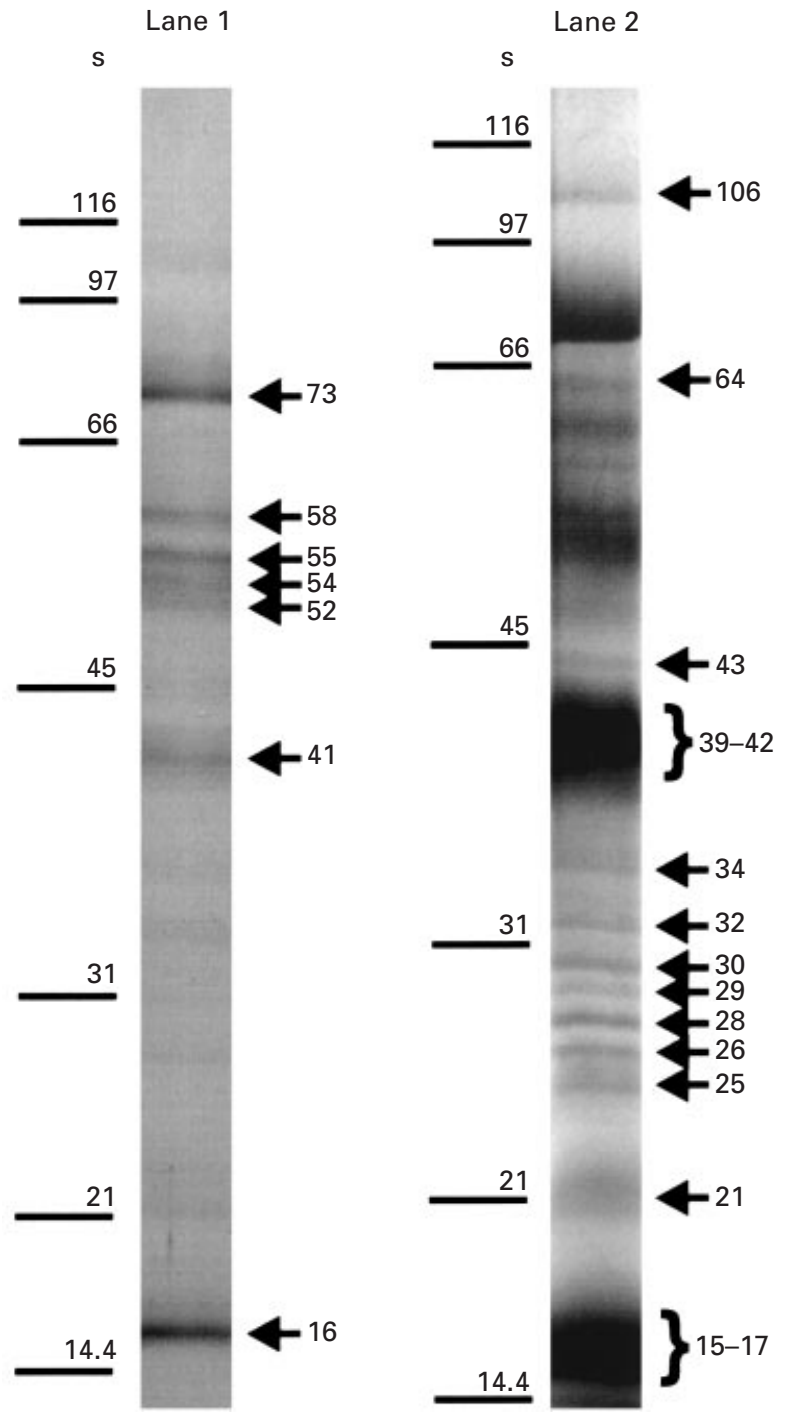

(b)

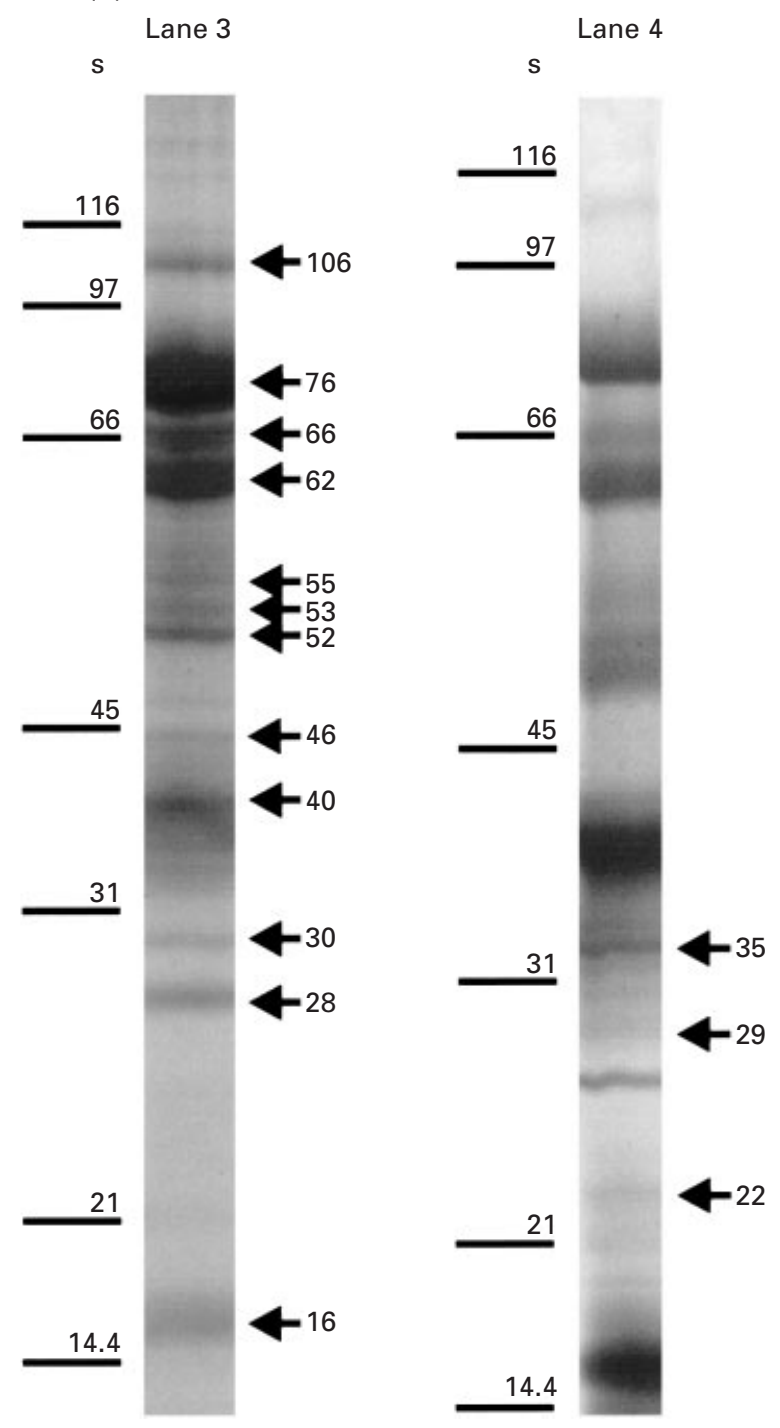

Fig. 5. One-dimensional SDS-PAGE of (a) total possum outer dense fibres stained with Coomassie brilliant blue (lane 1) and silver (lane 2), and (b) total possum fibrous sheath stained with Coomassie brilliant blue (lane 3) and silver (lane 4). Seven major and 11 minor outer dense fibre protein bands are visible, and 12 major and three minor fibrous sheath protein bands are visible. S: molecular mass standards.

The results of the present study demonstrate that techniques developed by Olson et al. (1976) and Olson and Sammons (1980) and later modified by Oko (1988) to isolate outer dense fibres and fibrous sheath from eutherian spermatozoa can be satisfactorily applied, with minor modifications, to extract a relatively pure protein fraction of these cytoskeletal components from possum spermatozoa. In the initial separation of possum sperm heads from tails, shorter and fewer bursts of sonication were needed than has been required in studies carried out on spermatozoa of laboratory rats (Oko, 1988; Kim et al., 1995a, 1999). The relative ease with which the heads separate from the tails of marsupial spermatozoa may be due to the mode of attachment of the tail to the fossa of the sperm head that occurs at the capitulum on the ventral surface of the head. This attachment may relate to less disulphide bonding of the material in this region in marsupials compared with in eutherian mammals (Bedford and Hoskins, 1990). Similarly, the force of centrifugation required to separate possum sperm heads from tails in a sucrose density gradient was only $3000 \mathrm{~g}$ (for $90 \mathrm{~min}$ ) compared with $100000 \mathrm{~g}$ (for $60 \mathrm{~min}$ ) required for rat spermatozoa (Oko, 1988; Kim et al., 1995a), indicating great differences in density of the possum sperm head and tail components compared with those of rats. Similar results have been reported in fractionation studies of tammar wallaby spermatozoa (Lin et al., 1998).

Incubation of isolated possum sperm tails in $1 \%(\mathrm{w} / \mathrm{v})$ SDS and $2 \mathrm{mmol}$ DTT $\mathrm{I}^{-1}$ resulted in a relatively pure 


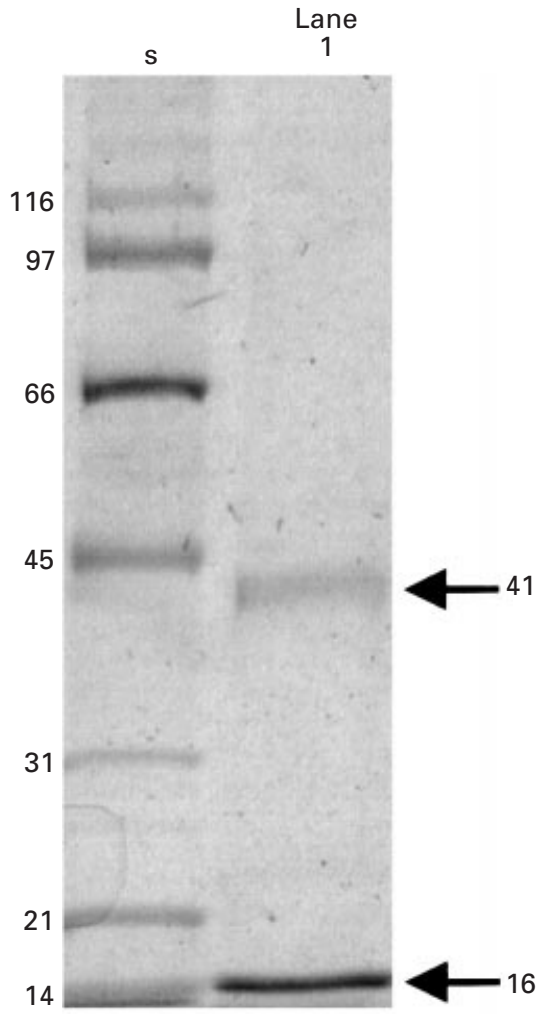

Fig. 6. One-dimensional SDS-PAGE of possum outer dense fibres after 120 min incubation of spermatozoa in SDS-dithiothreitol and staining with silver (lane 1). S: molecular mass standard.

fraction of outer dense fibres as determined by transmission electron microscopy. Seven major polypeptides were observed by Coomassie staining after solubilization and one-dimensional PAGE, with molecular masses of 73, 58, $55,54,52,41$ and $16 \mathrm{kDa}$. This number is similar to the number of major outer dense fibre proteins identified in laboratory rats (molecular masses: 84, 79, 66.2, 57.2, 29, 21 and $15.5 \mathrm{kDa}$ ) (Kim et al., 1999), although their molecular masses are somewhat different. Silver staining of the possum outer dense fibre gels revealed an additional 11 minor protein bands (molecular masses: 106, 64, 43, 34, $32,30,29,28,26,25$ and $21 \mathrm{kDa}$ ), compared with only five additional protein bands in silver-stained gels of rat outer dense fibres (molecular masses: 190, 150, 54, 48.5 and $44.6 \mathrm{kDa}$ ) (Kim et al., 1999). This finding indicates that either there are significantly more minor proteins in the outer dense fibres of possum spermatozoa than in rat spermatozoa or that there was minor contamination of the outer dense fibre fraction in the present study with, for example, proteins from remnants of the mitochondrial sheath. Unfortunately, our attempts to raise polyclonal antibodies to the possum outer dense fibres did not succeed and, therefore, we could not determine by immunogold labelling whether some of these proteins were from the mitochondrial sheath. Only three major outer dense fibre proteins have been reported in bulls (molecular masses: 85,
33 and $11 \mathrm{kDa}$ ) (Baccetti et al., 1973, 1976; Brito et al., 1986) and humans (molecular masses: 150, 67 and $55 \mathrm{kDa}$ ) (Haidl et al., 1991; Henkel et al., 1994). However, the detergent cetyltrimethylammonium (CTAB) rather than SDS was used in these studies, so it is possible that not all proteins were extracted and that additional proteins are present in the outer dense fibres of these species.

Ruthenium red fixation of possum spermatozoa from the cauda epididymidis showed that while the fibrous sheath was homogeneous, the possum outer dense fibre was composed of a narrow, electron dense, outer C-shaped cortex together with a central medulla. Similar morphological findings have been observed in the outer dense fibres of spermatozoa from several eutherian species, including the laboratory rat (Telkka et al., 1961; Bawa, 1963; Fawcett, 1970), indicating that there are ultrastructural similarities between the outer dense fibres of eutherians and the brushtail possum. Incubation of possum sperm tails in SDS and DTT for 90 min resulted not only in the isolation of the outer dense fibres, but also in the detachment of a thin fibre from the rest of the outer dense fibres. It is possible that this may, in fact, be the outer dense fibre cortex, which has become detached from the medulla during incubation. Prolonged incubation of the possum outer dense fibres in SDS and DTT resulted in solubilization of the thin segments, but the main part of the outer dense fibres, while swollen, remained largely intact and SDS-PAGE of this material revealed that only two of seven major possum outer dense fibre proteins ( 41 and $16 \mathrm{kDa}$ ) remained, indicating that these two proteins may be present in the medulla of the possum outer dense fibres.

In the present study, incubation of possum sperm tails in $2 \%(\mathrm{v} / \mathrm{v})$ Triton X-100 and $5 \mathrm{mmol}$ DTT $\mathrm{I}^{-1}$ followed by

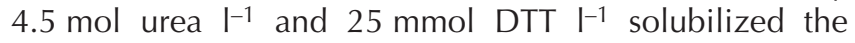
membranous flagella components and isolated the fibrous sheath as determined by TEM, although some remnants of the outer dense fibres remained. Residual outer dense fibre material has also been observed after identical incubations using spermatozoa from laboratory rats (Kim et al., 1995a) and rabbits (Kim et al., 1997). The possum fibrous sheath fraction had 12 major proteins, as shown by Coomassie staining, with molecular masses of 106, 76, 66, 62, 55, 53, 52, 46, 40, 30, 28 and $16 \mathrm{kDa}$, and an additional three protein bands (molecular masses: 35, 29 and $22 \mathrm{kDa}$ ) were identified by silver staining. In comparison, 17, 14 and 10 major fibrous sheath proteins have been identified in spermatozoa from rats (Kim et al., 1995a), humans and rabbits (Kim et al., 1997), respectively. Although the molecular masses of the fibrous sheath proteins in each species are somewhat different, the most prominent fibrous sheath proteins in rats and rabbits have molecular masses between 72 and $85 \mathrm{kDa}$. Likewise, in the present study on the brushtail possum, the most prominent protein had a molecular mass of $76 \mathrm{kDa}$. Whether this possum protein is homologous to the proteins of similar molecular masses in eutherian species has yet to be ascertained.

It is possible that the $106,55,52$ and $16 \mathrm{kDa}$ possum 

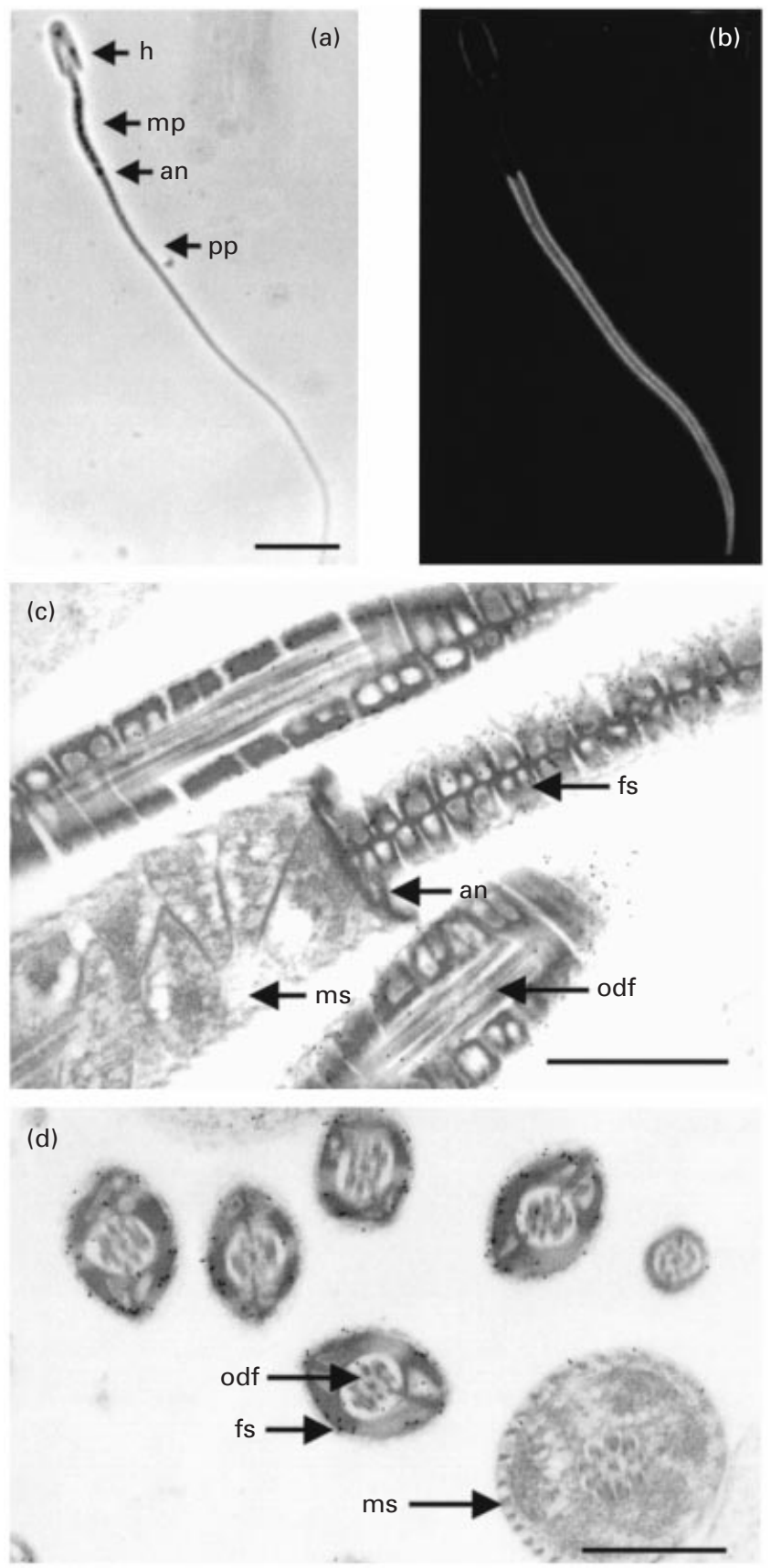

Fig. 7. Immunocytochemistry of possum spermatozoa incubated with antipossum fibrous sheath serum. (a) Phase-contrast micrograph and (b) corresponding fluorescent micrograph of a possum spermatozoon probed with possum fibrous sheath anti-serum. There is positive staining of the principal piece (pp), but no crossreactivity with the sperm head (h) or mid-piece (mp) was observed. an: annulus. Scale bar represents $10 \mu \mathrm{m}$. (c) Longitudinal and (d) transverse sections showing immunogold localization of the antibody to the fibrous sheath ( $\mathrm{fs}$ ) with no specific gold labelling observed over the outer dense fibres (odf) and mitochondrial sheath (ms). Scale bars represent $0.5 \mu \mathrm{m}$. 

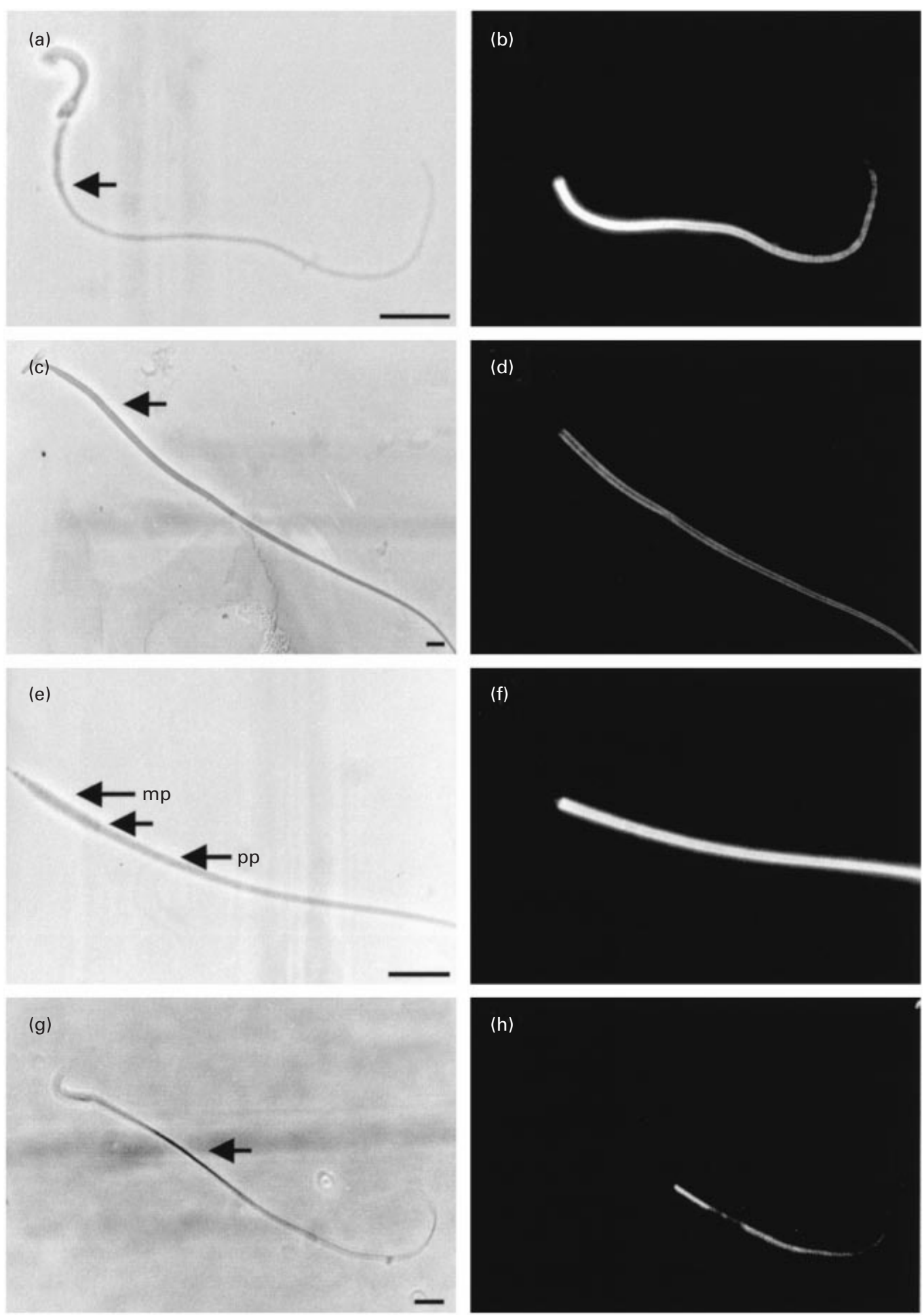

(h)

Fig. 8. Phase-contrast $(a, c, e, g)$ and corresponding immunofluorescent $(b, d, f, h)$ localization of the possum fibrous sheath antiserum to the principal piece of fixed, permeabilized spermatozoa from the cauda epididymidis of a $(\mathrm{a}, \mathrm{b})$ koala $(\mathrm{c}, \mathrm{d})$ dunnart, $(\mathrm{e}, \mathrm{f})$ wallaby and $(\mathrm{g}, \mathrm{h})$ laboratory rat. Strong fluorescence was observed on the principal piece (pp) of all species. mp: mid-piece; arrow: annulus. Scale bars represent $10 \mu \mathrm{m}$. 
(a)

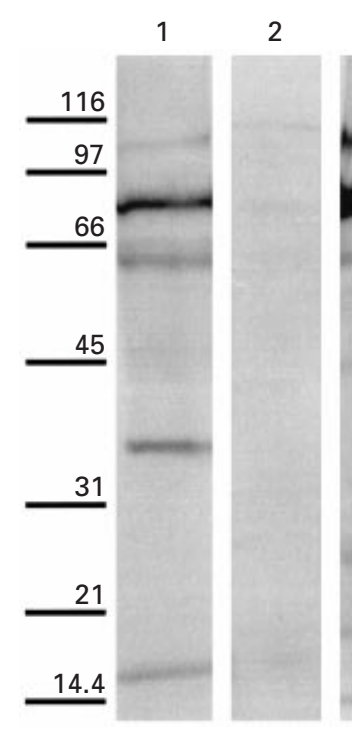

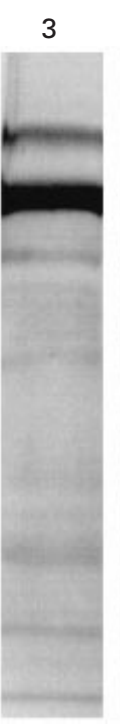

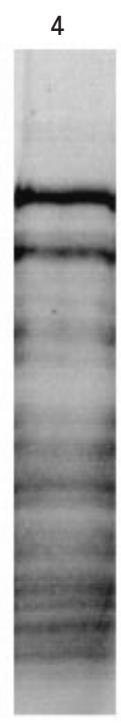

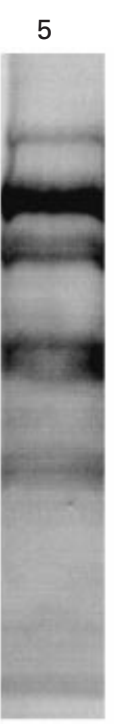

(b)

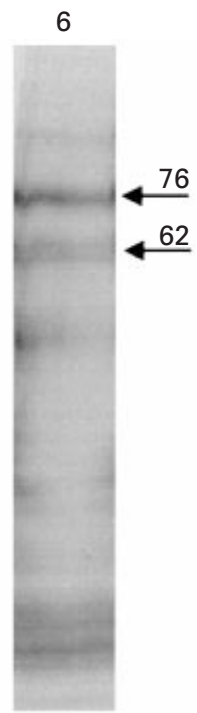

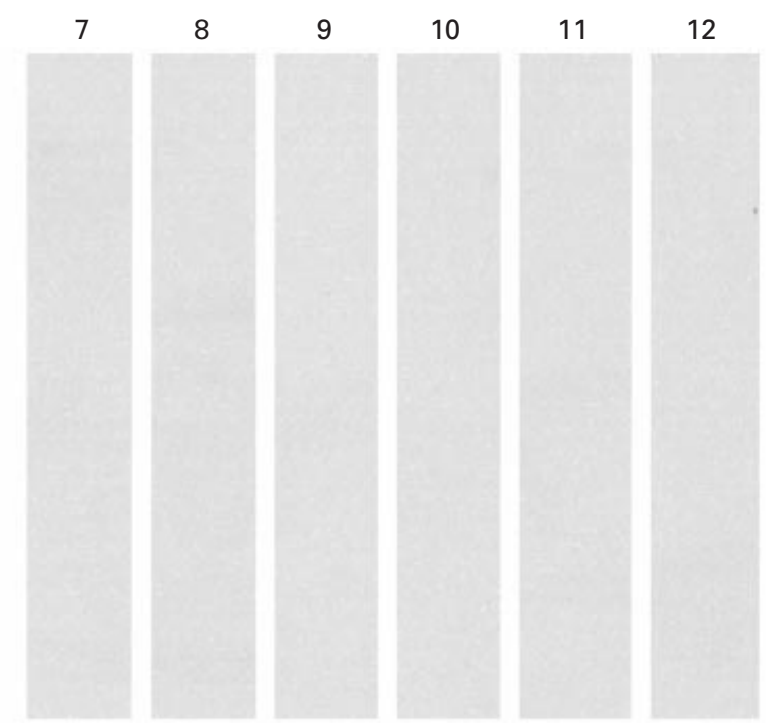

Fig. 9. Western blot of possum fibrous sheath (lane 1), possum outer dense fibres (lane 2) and laboratory rat (lane 3), wallaby (lane 4), dunnart (lane 5) and koala (lane 6) sperm polypeptides probed with a polyclonal antibody against the possum fibrous sheath. (a) and (b) are corresponding blots stained with immune and pre-immune sera, respectively. The antibody recognized most of the major possum fibrous sheath proteins (lane 1), but did not cross-react with the possum outer dense fibres (lane 2). Numerous proteins from rat, wallaby, dunnart and koala spermatozoa were immunostained in the blots, including the 76 and 62 kDa polypeptides in each species (lanes 3-6). No immunoreactive bands were detected in blots probed with pre-immune sera controls (lanes 7-12).

fibrous sheath proteins are contaminants from the outer dense fibres, as proteins of identical molecular masses are present in gels of the outer dense fibres. However, the outer dense fibre proteins did not immunostain when western blotting was carried out using the possum fibrous sheath antiserum. This finding indicates strongly that these proteins are not outer dense fibre contaminants and that the outer dense fibres and fibrous sheath are composed of different proteins. In rats, both the outer dense fibres and fibrous sheath were shown to contain 14.4 kDa proteins (Oko, 1988), and antibodies affinity-purified to each of these proteins were used to demonstrate immunocytochemically that these proteins, while antigenically similar, are not cross-contaminants (Oko, 1988). The possum fibrous sheath antiserum also did not bind to the mid-piece fibre network or connecting laminae of the marsupial sperm tails, indicating that the fibrous sheath proteins are unique and that a different suite of proteins is present in the other cytoskeletal structures. Harris and Rodger (1998) demonstrated that a $32 \mathrm{kDa}$ protein, identified by a monoclonal antibody PSA-10, occurs in the fibrous sheaths of possums and wallabies. This antibody was raised against possum acrosomal proteins, indicating that a fibrous sheath and acrosomal protein may be related. However, in the present study no binding of possum fibrous sheath antiserum to the acrosome or subacrosomal material was observed. In addition, no $32 \mathrm{kDa}$ protein was found in the gels run of the possum fibrous sheath, although minor proteins with molecular masses of 28, 29 and $30 \mathrm{kDa}$ were detected, and it is possible that one of these proteins corresponds to the protein recognized by the PSA-10 antibody.
In the present study, western blotting of possum outer dense fibres with anti-possum fibrous sheath serum demonstrated that, although there were no common proteins in the outer dense fibres, mid-piece fibre network or connecting laminae to which the possum fibrous sheath antiserum bound, there was marked crossreactivity with the fibrous sheath from spermatozoa of the dunnart, koala, wallaby and laboratory rat. The possum fibrous sheath antiserum recognized seven proteins from rats with molecular masses of 106, 76, 62, 45, 27, 20 and $14 \mathrm{kDa}$, which correspond roughly to the molecular masses of most of the major rat fibrous sheath proteins reported previously (Oko, 1988; Kim et al., 1995a). This finding indicates that the possum fibrous sheath antiserum may have recognized many of the fibrous sheath proteins from the dunnart, koala and wallaby, including the 76 and $62 \mathrm{kDa}$ proteins in all four species. The fact that the antibody recognized proteins of identical or similar molecular masses in spermatozoa of laboratory rats, dunnarts, koalas and wallabies indicates that these proteins may be highly conserved in the fibrous sheath both between marsupial species of three different families and laboratory rats. As eutherians and marsupials diverged over 100 million years ago, this finding indicates a remarkably high degree of conservation of these proteins across both eutherian and marsupial mammals, although these proteins do not appear to be present in the other cytoskeletal structures of the sperm head and tail.

For further determination of the degree of similarity between marsupial cytoskeletal proteins and those in eutherians, it is necessary to sequence the genes that code 
for the major marsupial proteins. To date, a small number of eutherian sperm outer dense fibres and fibrous sheath proteins have been sequenced although the insolubility of these proteins and blocking at the $\mathrm{N}$-terminus have hampered progress in this field. The most prominent rat outer dense fibre protein, termed Odf1 with a molecular mass of $27 \mathrm{kDa}$, has been cloned (van der Hoorn, 1990; Burfeind and Hoyer-Fender, 1991; Morales et al., 1994), and the sequence of this protein is highly conserved in mice (Hoyer-Fender et al., 1995), humans (Gastmann et al., 1993), bulls and boars (Kim et al., 1995b). The C-terminus of Odf1 contains a repetitive cysteine-glycine-proline motif that is also present in the Drosophila Mst87F gene product (Schäfer et al., 1993), a member of a gene family that encodes satellite fibres in the Drosophila sperm tail, which may be structural homologues of the mammalian outer dense fibres (Kuhn et al., 1988; Schäfer et al., 1993). These resemblances may reflect evolutionary conservation of these proteins from insects to mammals (Schäfer et al., 1993; Morales et al., 1994), although no $27 \mathrm{kDa}$ possum outer dense fibre protein was detected in the present study. Other outer dense fibre proteins the genes of which have been sequenced include an $84 \mathrm{kDa}$ rat outer dense fibre protein, termed Odf2, which has been proposed to interact with Odf1 via leucine zippers (Shao et al., 1997; Schalles et al., 1998), and a third rat outer dense fibre gene that encodes highly variable transcripts that translate into proteins of 65-75 kDa (Brohmann et al., 1997). Of the fibrous sheath proteins sequenced, most interest surrounds the major $82 \mathrm{kDa}$ mouse fibrous sheath protein, as it is an A-kinase anchoring protein (AKAP) (Carrera et al., 1994; Fulcher et al., 1995), which anchors protein kinase $A$, the major downstream target of cyclic AMP, to the sperm tail cytoskeleton; therefore, it may be involved in sperm motility (Miki and Eddy, 1988; Mei et al., 1997; Vijayaraghaven et al., 1997). Homologues of this protein have also been found in human (Turner et al., 1998), bull (Moss et al., 1999) and rat (El-Alfy et al., 1999) spermatozoa, and it would be interesting to determine whether the major possum fibrous sheath protein, which has a similar molecular mass, is also an AKAP.

In conclusion, the outer dense fibres and fibrous sheath have been isolated from the sperm tail of a marsupial species, the brushtail possum, and the molecular masses of the major proteins have been determined. Antiserum raised against the major fibrous sheath proteins did not crossreact with proteins in the outer dense fibres or other sperm cytoskeletal structures, thus indicating that these fibrous sheath proteins are unique. However, these fibrous sheath proteins appear to be conserved across marsupials and even a eutherian species.

The authors wish to thank C. Leigh and G. Penney for their technical assistance, and I. Hough for koala material. M. Ricci was in receipt of an Australian Postgraduate Award. This work was supported, in part, by an ARC grant.

\section{References}

Baccetti B, Pallini V and Burrini AG (1973) The accessory fibres of the sperm tail I. Structure and chemical composition of the bull coarse fibres Journal of Submicroscopic Cytology 52 237-256

Baccetti B, Pallini V and Burrini AG (1976) The accessory fibres of the sperm tail II. Their role in binding zinc in mammals and cephalopods Journal of Submicroscopic Cytology 54 261-275

Bawa SR (1963) Outer coarse fibres of the mammalian sperm tail - an electron microscope study Journal of Ultrastructure Research 9 475-483

Bedford JM and Hoskins DD (1990) The mammalian spermatozoon: morphology, biochemistry and physiology. In Marshall's Physiology of Reproduction pp 379-568 Ed. GE Lamming. Churchill Livingstone, New York

Brito M, Figueroa J, Vera JC, Cortés P and Hott R (1986) Phosphoproteins are structural components of bull sperm outer dense fibres Gamete Research 15 327-336

Brohmann H, Pinnecke S and Hoyer-Fender S (1997) Identification and characterization of new cDNAs encoding outer dense fiber proteins of rat sperm Journal of Biological Chemistry 272 10327-10332

Burfeind P and Hoyer-Fender S (1991) Sequence and developmental expression of mRNA encoding a putative protein of rat sperm outer dense fibres Developmental Biology 148 195-204

Carrera A, Gerton GL and Moss SB (1994) The major fibrous sheath polypeptide of mouse sperm: structural and functional similarities to the A-kinase anchoring protein Developmental Biology $165272-284$

Cleland KW and Rothschild FRS (1958) The bandicoot spermatozoon: an electron microscope study of the tail Proceedings of the Royal Society of London 150 24-42

El-Alfy M, Moshonas D, Morales CR and Oko R (1999) Molecular cloning and developmental expression of the major fibrous sheath protein (fibrous sheath 75) of rat sperm Journal of Andrology 20 307-318

Fawcett DW (1970) A comparative view of sperm ultrastructure Biology of Reproduction 2 (Supplement 2) 90-127

Fawcett DW (1975) The mammalian spermatozoon Developmental Biology 44 394-436

Fulcher MD, Mori C, Welch JE, O'Brien DA, Klapper DG and Eddy EM (1995) Characterization of Fsc1 cDNA for a mouse sperm fibrous sheath component Biology of Reproduction 52 41-49

Gastmann C, Burfeind P, Günther E, Hameister H, Szpirer C and HoyerFender S (1993) Sequence, expression, and chromosomal assignment of a human sperm outer dense fiber gene Molecular Reproduction and Development 36 407-418

Haidl G, Becker A and Henkel R (1991) Poor development of the outer dense fibres as a major cause of tail abnormalities in the spermatozoa of astherotertozoospermic men Human Reproduction 6 1431-1438

Harding HR, Carrick FN and Shorey CD (1979) Special features of sperm structure and function in marsupials. In The Spermatozoon pp 289-303 Eds DW Fawcett and JM Bedford. Urban and Schwarzenberg Inc., Baltimore

Harris MS and Rodger JC (1998) Characterisation of fibrous sheath and midpiece fibre network polypeptides of marsupial spermatozoa with a monoclonal antibody Molecular Reproduction and Development $\mathbf{5 0}$ 461-473

Henkel R, Stalf T, Mertens N, Miska W and Schill WB (1994) Outer dense fibres of human spermatozoa: partial characterization and possible physiological functions International Journal of Andrology 17 68-73

Hoyer-Fender S, Burfeind P and Hameister H (1995) Sequence of mouse Odf1 cDNA and its chromosomal localization: extension of the lineage group between human chromosome 8 and mouse chromosome 15 Cytogenetics and Cell Genetics 70 200-204

Jassim A (1995) Molecular and ontogenic analysis of the human sperm tail fibrous sheath. In Advances in Spermatozoal Phylogeny and Taxonomy Tome 166, pp 431-436 Eds BGM Ausio and J-L Justine. Mémoires Du Muséum National D'Histoire Naturelle, Paris

Jassim A, Gillot DJ, Al-Zuhdi Y, Gray A, Foxton R and Bottazzo GF (1992) Isolation and biochemical characterization of the human sperm tail fibrous sheath Human Reproduction 7 86-94

Kim YH, McFarlane JR, Almahbobi G, Stanton PG, Temple-Smith PD and 
deKrester DM (1995a) Isolation and partial characterisation of rat sperm tail fibrous sheath proteins and comparison with rabbit and human spermatozoa using a polyclonal antiserum Journal of Reproduction and Fertility 104 107-114

Kim YH, Adham IM, Haack T, Kremling H and Engel W (1995b) Molecular cloning and characterisation of the bovine and porcine outer dense fibers cDNA and organization of the bovine gene Biological Chemistry Hoppe-Seyler 376 431-435

Kim YH, deKrester DM, Temple-Smith PD, Hearn MTW and McFarlane JR (1997) Isolation and characterization of human and rabbit sperm tail fibrous sheath Molecular Human Reproduction 3 307-313

Kim YH, McFarlane JR, O'Bryan MK, Almahbobi G, Temple-Smith PD and deKrester DM (1999) Isolation and characterization of rat sperm tail outer dense fibres and comparison with rabbit and human spermatozoa using a polyclonal antiserum Journal of Reproduction and Fertility $\mathbf{1 1 6}$ 345-353

Kuhn R, Schäfer U and Schäfer M (1988) Cis-acting regions sufficient for spermatocyte-specific transcriptional and spermatid-specific translational control of the Drosphila melanogaster gene mst(3)gl-9 EMBO Journal $7447-454$

Lin M, Zhang X, Wade M, Harris M and Nickel M (1998) Isolation of proteins from subacrosomal region of spermatozoa from a marsupial, the tammar wallaby (Macropus eugenii). Journal of Reproduction and Fertility $113257-267$

Lindemann CB (1996) Functional significance of the outer dense fibers of mammalian sperm examined by computer simulations with the geometric clutch model Cell Motility and the Cytoskeleton 34 258-270

Lindemann CB, Orlando A and Kanous KS (1992) The flagellar beat of rat sperm is organized by the interaction of two functionally distinct populations of dynein bridges with a stable central axonemal partition Journal of Cell Science 102 249-260

Mei X, Singh IS, Erlichman J and Orr GA (1997) Cloning and characterization of a testis-specific, developmentally regulated Akinase-anchoring protein (TAKAP-80) present on the fibrous sheath of rat sperm European Journal of Biochemistry 246 425-432

Miki K and Eddy EM (1998) Identification of tethering domains for protein kinase A type I alpha regulatory subunits on sperm fibrous sheath protein Fsc1 Journal of Biological Chemistry 273 34384-34390

Morales CR, Oko R and Clermont Y (1994) Molecular cloning and developmental expression of an mRNA encoding the $27 \mathrm{kDa}$ outer dense fibre protein of rat spermatozoa Molecular Reproduction and Development 37 229-240

Moss SB, Turner RMO, Burkert KL, Vanscoy H and Gerton GL (1999) Conservation and function of a bovine sperm A-kinase anchor protein homologous to mouse AKAP82 Biology of Reproduction 61 335-342

Oko R (1988) Comparative analysis of proteins from the fibrous sheath and outer dense fibres of rat spermatozoa Biology of Reproduction 39 169-182
Olson GE and Sammons DW (1980) Structural chemistry of outer dense fibres of rat sperm Biology of Reproduction 22 319-332

Olson GE, Hamilton DW and Fawcett DW (1976) Isolation and characterization of the fibrous sheaths of rat epididymal spermatozoa Biology of Reproduction 14 517-530

Phillips DM (1972) Comparative analysis of mammalian sperm motility Journal of Cell Biology 53 561-573

Schäfer M, Börsch D, Hulster A and Schäfer U (1993) Expression of a gene duplication encoding conserved sperm tail proteins is translationally regulated in Drosophila melanogaster. Molecular and Cellular Biology 13 1708-1718

Schalles U, Shao X, van der Hoorn FA and Oko R (1998) Developmental expression of the $84-\mathrm{kDa}$ outer dense fibres sperm protein: localization to both the cortex and medulla of outer dense fibers and to the connecting piece Developmental Biology 199 250-260

Shao X, Tarnasky HA, Schalles V, Oko R and van der Hoorn FA (1997) Interactional cloning of the $84 \mathrm{kDa}$ major outer dense fiber protein Odf84 - leucine zippers mediate associations of Odf 84 and Odf 27 Journal of Biological Chemistry 272 6105-6113

Si Y and Okuno M (1993) The sliding of the fibrous sheath through the axoneme proximally together with microtubule extrusion Experimental Cell Research 208 170-174

Telkka A, Fawcett DW and Christensen AK (1961) Further observations on the structure of the mammalian sperm tail The Anatomical Record $\mathbf{1 4 1}$ 231-246

Temple-Smith PD (1987) Sperm structure and marsupial phylogeny. In Possums and Opossums: Studies in Evolution pp 171-193 Ed. M Archer. The Royal Zoological Society of New South Wales and Surrey, Beatty and Sons, Sydney

Temple-Smith PD (1994) Comparative structure and function of marsupia spermatozoa Reproduction, Fertility and Development 6 421-435

Turner RMO, Johnson LR, Haig-Ladewig L, Gerton GL and Moss SB (1998 An X-linked gene encodes a major human sperm fibrous sheath protein, hAKAP82 Journal of Biological Chemistry 27 32135-32141

van der Hoorn FA, Tarnasky HA and Nordeen SK (1990) A new rat gene RT7 is specifically expressed during spermatogenesis Developmental Biology 142 147-154

Vera JC, Brito M, Zuvic T and Burzio LO (1984) Polypeptide composition of rat sperm outer dense fibers - a simple procedure to isolate the fibrillar complex Journal of Biological Chemistry 259 5970-5977

Vijayaraghaven S, Goueli SA, Davey MP and Carr DW (1997) Protein kinase A-anchoring inhibitor peptides arrest mammalian sperm motility Journal of Biological Chemistry 272 4747-4752

Received 15 June 2000.

Accepted 27 September 2000. 